\title{
РАДІСТЬ ЯК ЦІННІСНО-СМИСЛОВИЙ ФЕНОМЕН У ТЕКСТІ КНИГИ СПОГАДІВ ІРИНИ ЖИЛЕНКО «НОМО FERIENS»
}

\begin{abstract}
Представлено результати феноменологічного підходу до індивідуально-авторського осягнення радості як ціннісного смислу, що генерується в процесі породження тексту. Засвідчено інтенційну присутність феномена радості у свідомості письменниці Ірини Жиленко. Описано здійснення інтенції засобом актуалізації ціннісного відношення як основи формування в тексті ціннісного смислу, що реалізується під радикалом модусу. Окреслено надфразні єдності, релевантні для дискурсивного розгортання смислу з огляду на характер модусної організації їхньої глибинної структури та лексико-семантичне й синтаксичне оформлення поверхневої структури. 3'ясовано специфіку апріорно-апостеріорного синтезу осмислення радості як ціннісного феномена.
\end{abstract}

Ключові слова: текст, смисл, інтенція, ціннісне відношення, модус, надфразна єдність, авторська формула, ідіоглоса.

Zaoborna M. S. Joy as a Value-Sense Phenomenon in the Text of the Book of Memoirs by Irina Zhilenko «Homo feriens». The article presents the phenomenological approach to the individual-author's reflection of joy as a value sense generated in the process of text production. The topicality of the study is determined by the need to comprehend the essential phenomena, which comprise certain aspects of a person's outlook related to emotions in the process of life activity. Linguistic boundaries of the problems are largely due to the specific feature of the text, which is consistent with its ability to actualize the phenomena of the world, where the author's consciousness reaches, with the help of the means of the lingual code.

The purpose of the article is to present the text of the book of memoirs «Homo feriens» in the aspect of individually-authoring comprehension of the knowledge about the emotional plan of the person, which is connected with the realization of the phenomenon of joy as a universal sense. In accordance with the goal the following tasks have been put: to highlight text segments that correlate with the translation of value sense of «joy»; trace the deployment of a defined value sense under the modus radical; to define lingual signals for actualization of value sense; to characterize the phenomenon of joy in the aspect of the dichotomy of apriori and aposteriori senses.

The suggested method of phenomenological analysis revealed the intentional presence of the phenomenon of joy in the mind of the writer. The reason for this was the allocation of a semantically integral system of author idiogloses, which in the text statements express a personally-subjective value relationship, which is realized as an intention, the implementation of which leads to the discursive deployment of sense, fixed by the outline in the text of the supraphrase unities, marked by the specificity of the modus-like organization of the deep structures in the text.

The results of the analysis produce generalizations that are relevant to apriori and aposteriori character perception of the phenomenon of joy as a text sense: 1 . The reflection of joy as the current apriori text sense is carried out within the context being formed by means of the lexicalsemantic and syntactic organization of supraphrase unities, and is characterized by the outline of the faces that reveal individual and authorial accents in understanding of this phenomenon in view of the actualization of other phenomena relevant to its comprehension, intentionally present in the mind of the writer. 2. The embedding of the basic textual sense, fulfilling the author's intention, is accompanied by the generation of specific aposteriori sense, denoted by the affirmation of the phenomenon of joy as a value and associated with the actualization of the so-called author's formulas in the structure of supraphrase unities.

Key words: text, sense, intention, value relation, modus, supraphrase unity, author's formula, idioglos. 
Енергетичним імпульсом до пропонованих у статті міркувань стала особистість професора Харківського національного педагогічного університету імені Г. С. Сковороди Сергія Івановича Дорошенка (1924-2018), яка в рецепції автора завжди узгоджувалась із переживанням радості: «Радісно біля Сергія Івановича. Радість - у його чистих очах, у дзвінкому сміхові. Радість - у спогадах про післявоєнні студентські роки. Радість - у спокійній оцінці свого життя. Радість - у згадці про зустріч з Галиною Олександрівною, у розповідях про свою родину. Радість - у родинному святкуванні Дня Перемоги. Та й навіть тональність його оповідей про ті чи ті буденні перипетії не наводить на думки про сірість людських буднів» (Заоборна, 2014: 402). 3 другого боку, у системі читацьких преференцій автора з огляду на інтуїтивне відчуття близькості смислів вирізняється постать української поетки-шістдесятниці Ірини Жиленко, яка в книзі спогадів «Homo feriens» («Людина святкуюча») визначає радість як «сіль» власної індивідуальності: «Я щаслива людина. Люблю життя. Вдячна долі за те, що мене обминули спокуси вульгарного споживацтва, кар'єризму, фанатичного аскетизму, залишивши мені просте і добре, багатотрудне і радісне людське життя. Радісне не «тому, що ...», а «незважаючи на ...». І люди, і держава потрудились немало, аби згасити радість (відблиск раю!) в моїй душі.... Владі не подобались джерела мого «оптимізму» (бо ж в усьому і завжди примітивна душа шукає першопричину). Як сміє, мовляв, поет радіти не успіхам радянської доби, а вікну, відчиненому в сад, осінній меланхолії, якомусь там коту на підвіконні або клаптикові музики з чужого вікна - всій цій естетській (класово ворожій пролетаріату) мішурі? Друзі ж, державні опозиціонери (на щастя, далеко не всі) гнівно вигукували: «Як можна в такі часи (!) писати вірші, пронизані якоюсь незрозумілою радістю?» (Жиленко, 2011: 21-22). Увиразнення феномену радості на тлі переживання постатей двох світлих людей із неповторним відчуттям Краси й Слова актуалізує думку О. Потебні про те, що індивідуальне виростає з національного, яке, своєю чергою, пов'язане 3 мовою (Потебня, 1993: 174-176), і стимулює вихід особистісного рецептивно-комунікативного сприйняття тексту «Ноmo feriens» у ширший контекст, пов'язаний із лінгвістичним радикалом усвідомленням тексту як «генератора смислів» (Ю. Лотман).

\section{Вступ}

Антропна спрямованість сучасного мовознавства добротно підтримується такою його фундаментальною рисою, як текстоцентризм. Текст, будучи осердям дослідницької парадигми гуманітарної сфери знань загалом, ставить перед лінгвістикою нові проблеми, пов'язані насамперед із дискурсивно-текстовою діяльністю людини як транслятора смислів і суб'єкта текстотворення. Як зауважують, апелюючи до думки сучасного психолога й культуролога Вадима Руднєва, автори праці «Лінгвістика тексту» Флорій Бацевич та Ірина Кочан, «людина - це текст, який вона пише все життя і залишає після себе; аналізуючи текст, можна багато чого сказати про людину і час, в якому вона жила» (Бацевич \& Кочан, 2016: 34). 
Певним викликом сьогодення стала для сучасної людини проблема емоційного інтелекту, що полягає у виробленні здатності ефективно керувати своєю емоційною сферою (Вайсбах \& Дакс, 1998; Гоулман, 2018). 3 другого боку, у сучасному суспільстві на тлі актуалізації в ньому синдрому емоційного вигорання все частіше виникає потреба в осмисленні феномена радості (Ермакова, 2010; Орел, 2005). Лінгвістика тексту в цьому плані може прислужитись з огляду на те, що, по-перше, саме в тексті людина втілює «постійну потребу усвідомлювати, осмислювати, чітко розуміти те, що відбувається навколо і в ній самій» (Бацевич \& Кочан, 2016: 269), по-друге, визнання тісного взаємозв'язку пізнавальної й мовної діяльності та розуміння мови як основного способу контакту зі світом, а також основи свідомості, мислення й особистості окреслює шлях до раціонального осмислення емоційного життя людини на основі аналізу процесу його вербалізації в тексті.

Актуальність пропонованого дослідження визначається необхідністю осмислення сутнісних феноменів, що становлять пов'язані з емоційним життям ті чи ті аспекти світовідчуття людини в процесі її життєдіяльності. Лінгвістичний радикал проблеми значною мірою зумовлений специфічною особливістю тексту, що узгоджується з його здатністю актуалізувати засобами мовного коду феномени того світу, куди сягає авторська свідомість.

Постановка проблеми. Усвідомлення мови як феномена, що здійснює «втілення заданих смислів у відповідні тексти та заданих текстів у відповідні їм смисли» (Мельчук, 1974: 9), а процесу текстотворення як руху людської думки «від індивідуальних авторських смислів до їх утілення в узуалізовані мовні значення» (Бацевич \& Кочан, 2016: 288) передбачає актуалізацію смислу як феномена культурної реальності й атрибуту мисленнєвої та розумової діяльності людини. На цьому тлі кожен окремий текст засобами мовного коду увиразнює неповторність еманації в «життєвому світі» (Е. Гуссерль) індивіда як формі соціокультурної презентації світу та людини в ньому тих узагальнених смислів, що є точками зіткнення людини й світу, відповідають присутності людини у світі й визначаються як цінності. Ідеться про такі смисли, як «життя», «краса», «істина», «добро», «свобода», що, будучи конституантами «ціннісно-смислового Універсуму» (С. Кримський), формують підгрунтя світогляду особистості. Водночас рівнева структура світогляду, диференціюючи світовідчуття, світосприйняття та світорозуміння (Нестеренко, 1995: 82-84), мотивує виділення в системі цінностей смисли, пов'язані з аспектами чуттєво-емоційної форми переживання людиною світу та своєї позиції в ньому. Ідеться про такі грані світовідчуття, як-от, наприклад, «любов», «радість», «співчуття».

Пов'язаний з індивідуальною свідомістю життєвий світ індивіда як рухомий горизонт смислів передбачає звернення до мови конкретного індивіда, аналіз її функціонування з точки зору цього індивіда, позаяк «мова як “орган внутрішнього буття індивіда" (В. фон Гумбольдт) окреслює сферу його внутрішнього життя, доступну для раціональної рефлексії, конституює суб'єктивну реальність людини та сферу її життєвого світу. Будучи конститутивною стосовно суб'єктивної реальності людини, природна мова виступає 
“будівельним матеріалом” власного Я» (Смирнова, 2017: 13). У цьому плані привертають увагу текстові форми втілення мемуарного дискурсу (так званої «літератури факту»), представленого спогадами, листами, щоденниками.

Аналіз досліджень і публікацій із поставленої проблеми. Здатність людини транслювати смисли, яка узгоджується з ії̈ здатністю будувати тексти, увиразнюється в лінгвістичних дослідженнях, що стосуються когнітивної та комунікативно-прагматичної площин сучасного мовознавства. 3 одного боку, розглядається смисл як підгрунтя для формування системно пов'язаних текстових концептів (Кононенко, 2012), а також актуалізується проблема пов'язаного з інтенцією ціннісного смислу, що розгортається в художньому тексті як ціннісне відношення до експліцитного ціннісного концепту - маніфестованої цінності, що виступає однією з констант внутрішнього світу суб’єкта (Маринчак, 2004). 3 другого боку, продукується розуміння смислу в аспекті діяльнісного виміру мови, тобто іії використання з позицій цілей та інтересів людини в ії̈ вербальній взаємодії з іншими людьми (Бацевич, 2004, 2008; Сазонова, 2017). У цьому плані смисл визначається як інтенція учасників спілкування, певна результуюча апріорних та апостеріорних чинників, що відповідно стосуються відкладених у свідомості індивіда світоглядних, психічних, психологічних, ментальних, комунікативних установок і тих соціальних, психологічних, когнітивних, контекстних, ситуативних впливів, які виявляються в умовах побудови та сприйняття таких комунікативних одиниць, як мовленнєві акти, мовленнєві жанри, дискурси (тексти).

Виділені площини актуалізують увагу до контекстів реалізації смислів, а також особливостей організації глибинної й поверхневої структур текстових одиниць, де ці смисли формуються. На цьому тлі окреслюється модусний радикал реалізації механізму розгортання ціннісного смислу «краса» як втілення точки зору письменниці Ірини Жиленко в процесі породження тексту книги спогадів «Ноmo feriens», унаслідок чого виділяються специфічно організовані текстові одиниці - надфразні єдності, що усвідомлюються як «лінгвістично релевантні для когнітивного процесу сутності, певні коди ціннісно-смислового простору автора», у яких функціонують лінгвальні сигнали ціннісного смислу - лексеми-ідіоглоси як «своєрідний вияв скерованої на осягнення цінності інтенціональної свідомості автора» (Заоборна, 2016: 177). Проведене дослідження активує інтерес до вияву механізмів актуалізації інших феноменів ціннісно-смислового простору Ірини Жиленко, серед яких пріоритетним, безумовно, виступає «радість».

Мета статті - представити текстову дійсність книги спогадів «Ното feriens» в аспекті індивідуально-авторського ословлення того знання про емоційний план особистості, що пов'язане з усвідомленням феномена радості: Відповідно до мети ставляться завдання: 1) виділити текстові сегменти, що корелюють із трансляцією ціннісного смислу «радість»; 2) простежити характер розгортання окресленого ціннісного смислу під радикалом модусу; 3) визначити лінгвальні сигнали актуалізації ціннісно-смислового феномена; 4) увиразнити феномен радості в аспекті дихотомії апріорних та апостеріорних смислів. 


\section{Методи та методики дослідження}

3'ясування характеру трансляції смислу в дискурсивно-текстовій діяльності індивіда передбачає звернення до пов'язаного з ідеями Е. Гуссерля методу феноменологічного аналізу (Гуссерль, 1994), у площині якого текст усвідомлюється як суб'єктивна інтерпретація дійсності, смисловий феномен, опредмечений знаками, що виступає результатом здійсненого автором інтенціонального синтезу (Гуссерль, 2001: 344). Опора на індивідуальну свідомість автора, сутнісною ознакою якої визначається інтенціональність, спрямованість на об'єкт, завдяки чому іiї стани «характеризуються як такі, що мають зміст, несуть у собі інформацію про щось, що є поза свідомістю» (Бацевич, 2010: 34), проектує застосування інтенціональної методики, яка виявляє, по-перше, феномени свідомості, що осмислюються суб'єктом (автором), по-друге, смисл, що відтворює точку зору суб'єкта в процесі усвідомлення й відповідного позначення актуалізованого феномена.

Інтенціональний акт, пов'язаний із конституюванням смислового феномена, здійснюється через реалізацію модусу як способу взаємодії особистості з так званим об'єктивним світом. Типологія модусів представлена Н. Д. Арутюновою й конкретизується такими планами, як перцептивний, ментальний, емотивний, вольовий (Арутюнова, 1999: 411). Це передбачає застосування методики процедурно-дискурсивного розгортання тексту, яка корелює з семіотичним методом, що представляє текст з позицій його знакової організації.

На цій основі радість увиразнюється як актуальний для свідомості Ірини Жиленко феномен, інтенціональне осмислення якого розгортається в процесі ії текстотвірної діяльності, утіленої в книзі спогадів «Ноmo feriens» (Жиленко, 2011).

\section{Результати та дискусії}

Радість як ціннісно-смисловий феномен у тексті книги спогадів Ірини Жиленко корелює з високою частотністю ключових лексем радість, paдісний, радісно, радіти та актуалізацією композитів радіснодушна (людина), радіснодушність, що утворюють семантично цілісну систему авторських ідіоглос. На цьому тлі інтенційна присутність феномена радості у свідомості письменниці увиразнюється функціонуванням буттєвих висловлень та експліцитною актуалізацією квантора існування: Радість - це відсвіт раю в людській душі. Він або $\boldsymbol{\epsilon}$, або його нема (с. 21); За вікном каркають ворони. $\boldsymbol{E}$ радість (с. 277).

Текст «Homo feriens» розгортає антропну площину осмислення радості, у якій виокремлюються синтагми на зразок радість буття земної людини; Бог осипає нас радісним небесним сріблом; радісне людське життя; радіснодушні люди; людина не може жити без радості. При цьому феномен радості як цінність не просто входить у фонд знань письменниці, а виявляється у зв'язку з персонально-суб'єктивним відношенням до нього, що позначається на функціонуванні висловлень, у семантичній структурі яких виділяється позиція авторизованого суб'єкта. Це відношення: а) виступає значущим для 
суб’єкта як константа його ідентичності: Поетеса я, можлливо, $і$ слабенька, зате радісна людиночка - на всі сто!!! (с. 410); ... Але й радість усю одразу прийняти було б несила... Вона бмене розлила і понесла. І не було б Ірини Жиленко, а була б сама Радість, і нічого, окрім радості. Може, це і є рай?; б) існує як щось специфічно персональне, закорінене у внутрішньому світі суб'єкта: Я сильна оцим могутнім і прекрасним почуттям радості буття (с. 697); в) реалізується як чинник, що мотивує інтенції суб'єкта: І якщо на самісінькому дні відчаю, на тому дні, з якого вже не піднімаються, - опиниться їі Світлість Ірина Жиленко, то на цьому дні одразу ж засвітиться свічка, зазвучить музика, потече білий нескінченний сніг і народиться Радість. I тоді дно стане небом, бо небо maм, де я (с. 23); г) наявне як фундаментальна потреба в повноті життя, що мотивує емоційні переживання суб'єкта: $A$ я все одно живу в якомусь щасливому нетерпінні, щомиті чекаючи од життя неймовірних, несподіваних дарунків і свят, аж щось радісно обривається всередині (с. 77); г) представлене як суб’єктивний стан, що мотивує поточні реакції, які позначаються на переживанні буття й релевантні для осягнення його цінностей: Отаким був наш учорашній день. Запам'яталась ейфорія і серие, що тане від щастя. І відчуття, що смерті немає, а є вічне, спокійне блаженство світу, Ярмарок Чудес. Коли я в радості - я вірю, вірю, вірю... Не знаю, у що, але вірю, що жодна жертва не марна, все буде виправдано і винагороджено. I що жде нас нескінченна, захоплююча Радість і Свобода (с. 409).

Ціннісне відношення реалізується як інтенція, яка здійснюється засобом переживання цінності, що слугує формуванню в тексті ціннісного смислу, який розгортається під певним модусним радикалом. У цьому плані увиразнюється апріорно-апостеріорний синтез осмислення радості як ціннісного феномена в тексті книги спогадів Ірини Жиленко.

Радість продукується як базовий, поточний апріорний текстовий смисл, що корелює з семантичною структурою лексеми радість, пов'язаною із реалізацією лексико-семантичного варіанта «Почуття задоволення, втіха, приємність» (Словник української мови, 1977: 436). Орієнтуючись на узуальне мовне значення, смисл генерується у надфразних єдностях тексту, які реалізують інформаційний тип мовлення, що розгортається з огляду на модусну організацію глибинної текстової структури, яку визначають:

- модус перцепції з елементами емотивного: Я відчинила вікно і не можу надихатись. Сьогодні я прокинулась о 6-й від щебету. І немов гарячою радісною хвилею облилось серце. Я живу-у-у! Я ненормально красива і шаслива (с. 116); ... Скоро кінець літу. Мов кінець світу - печально до сліз. Уже тішуся кожною миттю, і кожною миттю печалюсь. Якась ніжна, сумна і солодка приреченість. Покора... О 5-й ледь-ледь сіріє. Печальні, темні світанки, легкий шелест дошу, і в розчинене вікно - вологі запахи осіннього саду. О, які запахи! У цих вставаннях затемна свіжа й тремтлива осіння радість (с. 483);

- ментальний модус, що синтезує перцептивні та емотивні акти: Багато чого надбали кияни за проминулі півсторіччя. Але по дорозі до цивілізованого життя загубили ми радість голубнищвв. Оия сіренька, вимираюча неміч, яка ще животіє в Києві, - ие не голуби. Хай сірим було життя, зате у небі 
стільки голубиних кольорів, стільки порід, стільки назв (смішних і вже забутих). А скільки пристрастей! За будильник мені правив свист сусідського хлопчака, який бігав по дахові з довгою тичкою - ганяв голубів. І все небо розквітало ранковим салютом, лопотінням крил (с. 31); Серпеньлюблю найдужме. Уньому вже більше духовного, ніж плотського. Дими од вогнищ, запахи соломи, дощів, грибів,довгі, повільні прогулянки у поля, крики жсуравлів і лосів. Войовниче пустельництво, смуток і радість злиття з природою. Смуток, бо прощання з літом земним, а радість, бо знаю (як і природа знає), що смерть - це лиш зимові сни, від яких прокидаються (с. 481).

У межах актуалізованих надфразних єдностей конкретизуються граневі вияви базового апріорного смислу, що окреслюються з огляду на лексикосемантичне оформлення горизонтального контексту ідіоглос, які виступають мовними сигналами його трансляції, а також відповідно до семантики структурної схеми фіксованих синтаксичних конструкцій та позицій актуалізованих у них лексичних одиниць. На цій основі виявляються такі грані ціннісно-смислового феномена радості:

а) динамічно вітальна сутність: На иьому дні [відчаю - М. 3.] одразу ж⿻ засвітиться свічка, зазвучить музика, потече білий нескінченний сніг $і$ народиться Радість (с. 23); I не старіє серце, бо не старіє радість буття земної людини (с. 21);

б) детермінованість феноменами буття: радість буття (с. 21, 276, 697); радість голубництва (с. 31); радість дарувати і приймати подарунки (с. 26); радість жити й обстоювати благородні ідеали (с. 122); радість жити в иьому чарівному світі, радість дивитися на дітей, рослини, трави $і$ води, речі й картини; радість читати, слухати, торкати, нюхати, їсти-пити, хмеліти, плавати, любити, збігати босоніж по стежці з високої гори, блукати чи то лісом і полями, чи вуличками Києва, чи просто сидіти у своєму кріслі обличчям до весняного міста у вікні (с. 415); радість злиття з природою (с. 481); радість у вставаннях затемна (с. 483); радість духу (с. 483); радість безсмертя (с. 713); виконаним обов'язком (часто доволі обтяжливим): Коли все сяє чистотою, а ти, стогнучи й потираючи поперек, бухаєшся у своє декадентське крісло - $i$ раптом ... потрясний сплеск радості ілегкості від того, що прання - позаду, а у вікні стільки сония! (с. 666); інтелектуальним і вольовим зусиллям: Я насолоджуюся кожним прожитим днем, розуміючи, що другого такого ніколи не буде. Але й сподіваюсь завжди, що другий буде ще красивіший, і це дає мені радість $i$ любов до життя (с. 109); Ні, навіть у найстрашніші часи не можсна віддавати радості ворогам. Хай вона буде з нами! (с. 670);

в) інклюзивний характер вияву: Я не мислю собі ні краси, ні радості без позлітки (с. 47); це дає мені радість і любов до жсиття (с. 109); потрясний сплеск радості і легкості (с. 666); Я сильна оцим могутнім і прекрасним почутмям радості буття, вдячності за нього (с. 697); мить, яка стільки обіияє шаленої радості і неймовірного щастя (с. 713);

г) синкретична амбівалентність втілення: Пам'ять моя сліпне од радості і горя, згадуючи той останній наш щасливий Новий рік перед хресним часом репресій (с. 25); Болісно самотній вечір, у якому так гостро переплелись горе $\boldsymbol{i}$ 
несмілива радість, відиай і надія (с. 23); Войовниче пустельництво, смуток $\boldsymbol{i}$ радість злиття з природою (с. 481); Але ж там не буде отакого ранку і такої свіжої печальної радості (с. 483).

Граневі вияви поточного смислу, що транслюється в тексті, актуалізують феномени життєвого світу письменниці. Водночас окреслюються контексти, де ціннісне відношення як основа звершуваного смислу модифікується в напрямку формування інтенцій до збереження цього смислу, його утвердження в життєвій діяльності й творчості. Тим самим продукуються апостеріорні смисли, що реалізуються з огляду на піднесення персональносуб'єктивного ціннісного відношення до рівня узагальнення.

Пов'язані з ціннісно-смисловим феноменом радості апостеріорні смисли тексту книги спогадів Ірини Жиленко створюються в надфразних єдностях, яким властивий бінарний характер змістової організації. Йдеться про два етапи їх розгортання: 1) формування базового сегмента; 2) актуалізація текстових відрізків, що усвідомлюються як так звані авторські формули - особливі авторські знаки, «словесне тіло ідеї, що наділене внутрішньою формою й чіткою структурою та відтворює картину світу в авторському світовідчутті» (Шевченко, 2014: 29). Наприклад:

(1) Сьогодні мені дуже якось погано, гнітючо, природа не тішить ока, $і$ я почуваюсь безпорадною, загубленою, вилущеною з цілого світу, мов Сва, вигнана з раю. Почуваюсь відкритою всіляким інфекціям і радіації, буквально віч-на-віч зі смертю. // Коли жс я гостро і готовно, мов камертон, сприймаю красу світу, приймаю ї̈ в себе - $я$, здається, вже не вміщаюсь в самій собі, я впізнаю себе у троянді і осяяному сонщем дереві, в лінії гори і в кумедній пташині. Я вже не тільки «я». Я - всі, всі - я. Отже, зі мною весь білий світ стоїть супроти смерті. Я сильна оцим могутнім і прекрасним почуттям радості буття, вдячності за нього і впевненості в ньому, як в чомусь сталому, яке має мету, доцільність і безсмертя (с. 697);

(2) Київ заліплений снігом, підсинений новорічними присмерками і нереальний, мов казки Гофмана. Дивишся у вікно на фосфоресиуючі синню засніжені дахи - і очі стають величезними, дитинно-круглими, розкритими небові й землі, минулому і майбутньому. // Очі не старіють, бо не старіє краса. I не старіє серце, бо не старіс радість буття земної людини. Радість - це відсвіт раю в людській душі. Він або є, або його нема (с. 21);

(3) Нині м'який печальний ранок. Низько нависле небо, рідне до щему. Густо синіють буряки. Кричать сороки. І все це мов обіияє щось. Що? Коли? Восени? В Києві? Чи десь, колись, у тому житті, про яке ми не знаємо нічогісінько. Але ж там не буде отакого ранку і такої свіжої печальної радості. Хтозна, // головне, щоб була радість (с. 483).

Модуси, які лежать в основі реалізації такого типу надфразних єдностей, увиразнюються в опозиції «субстрат - суперстрат». Базовий сегмент формують перцептивний та/або емотивний модуси з можливим вкрапленням елементів ментального модусу. Авторські формули розгортаються під радикалом ментального модусу, що конкретизується як модус знання або думки (гадки), або вольового модусу. Модус знання - див. (1) - передбачає 
продукування авторських формул як формул внутрішнього досвіду, в семантичній структурі яких актуалізується позиція суб'єкта: [Я знаю, що] я сильна оцим могутнім і прекрасним почуттям радості буття. Модус думки - пор. (2) - породжує сентенції, в яких суб'єктний компонент змісту представлений узагальнено: [Я думаю, що] радість - ие відсвіт раю в людській душі (не в моїй душі, не в душі конкретного індивіда, у душі людини загалом). Під радикалом вольового модусу (3) формується життєвий імператив неактуалізованого суб'єкта, що утверджує цінність.

Авторські формули Ірини Жиленко виявляють індивідуально-особистісну неповторність осмислення радості, продукуючи парадигму апостеріорних смислів:

радість - дар, яким наділені вибрані люди (на цій смисловій основі творяться оказіональні композити радіснодушна (людина) і радіснодушність): Радість - це відсвіт раю в людській душі. Він або є, або його нема (с. 21); Радіснодушні люди - суспільні лінивці, бо їм «і так добре» (с. 410);

радість - абсолютна цінність, що існує сама в собі: Радіснодушність коштовність, як і всякий інший Божий дар. I чим безпричиновіша, природніша радість, тим вона коштовніша (с. 22);

радість - сутнісна потреба людини, реалізація якої забезпечує їі життєздатність: Але же людина не може жити без радості, особливо така маленька. Вона тупішає і озлоблюється (с. 666);

радість можлива лише за умови вільного протікання, у свободі від негативного емоційного баласту: $A$ з почуттям провини - яка вже там радість і яка поезія! (с. 127);

існує специфічна радість, переживання якої доступне лише дітям і поетам: Бо поет - вічне дитя, - і той поет, що віддає себе, i той, хто приймає, бере його в себе, шасливо і вдячно. І для обох (поета, що пише, і поета, шо читає) життя сповнене майже любострасної чуттєвої радості: кольори, звуки, дотики, запахи, рухи, жести. Все сповнене змісту і чекання шастя (с. 77);

радість виступає запорукою міцності людського духу: Коли я в радостія вірю, вірю, вірю...(с. с. 409); Я сильна оцим могутнім і прекрасним почуттям радості буття, вдячності за нього і впевненості в ньому, як в чомусь сталому, яке має мету, доцільність і безсмертя. Бо емоція не вагається і не сумнівається (c. 697);

радість - цінність, що передбачає збереження й утвердження, як і будьяка цінність людського буття: Потрібен багато вищий рівень мислення, ніж у радянської людини (та й пострадянської теж), щоб повторити услід за Камю: «Правда цього світу полягає в тому, що правди в ньому нема». Повторити, увірувати в це $і$... все-таки не впасти в цинізм і мізантропію, не втратити ні мужності, ані радості жити й обстоювати благородні ідеали (с. 122); Hi, навіть у найстрашніші часи не можна віддавати радості ворогам. Хай вона буде з нами! (с. 670).

Виділення авторських формул, що генерують пов’язані з феноменом радості суб'єктивні апостеріорні авторські смисли, актуалізує проблему увиразнення, диференціації, формалізації межі між ними та граневими виявами 
узуалізованого апріорного осмислення цього феномена, які теж достатньо прагматизовані. Тип контексту як тло, на якому реалізується опозиція способів модусної організації надфразних єдностей, що генерують ці смисли, не вичерпує всю глибину питання з огляду на те, що продукування авторських формул під радикалом ментального модусу не заперечує синхронну реалізацію граневих смислів, як-от, наприклад, у висловленні $A$ з почуттям провини - яка вже там радість і яка поезія!, де суб'єктивне осмислення умов реалізації радості здійснюється інклюзивно, актуалізуючи інтенційну присутність у свідомості суб'єкта поезії як суміжного ціннісного феномена. Водночас підняте дискусійне питання не заперечує результати дослідження, які передбачають можливість здійснення певних узагальнень, пов'язаних з актуалізацією радості як ціннісно-смислового феномена.

\section{Висновки}

Текст Ірини Жиленко виявляє специфіку індивідуально-авторського осмислення радості, на тлі якого продукуються міркування, релевантні для усвідомлення процесу трансляції смислу в дискурсивно-текстовій діяльності людини загалом.

1. Усвідомлення радості як ціннісного смислу в тексті книги спогадів Ірини Жиленко «Ноmo feriens» увиразнює персонально-суб'єктивне ціннісне відношення, що виступає підставою для реалізації смислу. На цій основі вирізняються: а) власне інтенція феномена радості, яку в тексті виявляють семантично цілісна система авторських ідіоглос і буттєві висловлення, марковані квантором існування; б) здійснення інтенції під радикалом модусу, що веде до дискурсивного розгортання смислу, яке закріплюється в оформленні надфразних єдностей, що виявляють опозицію способів модусної організації глибинної структури.

2. Формування надфразних єдностей узгоджується з актуалізацією текстових ідіоглос, що корелюють феноменологічно-смислове усвідомлення радості з узуальним мовним значенням і слугують лінгвальними сигналами апріорно-апостеріорного характеру трансляції феномена радості як текстового смислу.

3. Продукування радості як поточного апріорного текстового смислу в межах контексту, що формується лексико-семантичною та синтаксичною організацією надфразних єдностей, увиразнюється окресленням його граней, які виявляють індивідуально-авторські акценти в усвідомленні цього феномена з огляду на актуалізацію релевантних для його осмислення інших феноменів, інтенційно присутніх у свідомості письменниці.

4. Огранення базового текстового смислу, що звершує авторську інтенцію, супроводжується генеруванням специфічних апостеріорних смислів, пов'язаних з актуалізацією у структурі надфразних єдностей авторських формул, що узгоджуються з утвердженням феномена радості як цінності.

Загалом здійснений феноменологічний аналіз осмислення радості в тексті Ірини Жиленко не претендує на вичерпний аналіз цього ціннісного смислу. Водночас у ньому можна вбачати один із шляхів досягнення 
декларованої феноменологією ідеальної об'єктивності, оскільки в мові досвід людини втрачає суб'єктивні риси й стає доступним для всіх. На цій основі окреслюється перспектива дослідження, результати якого можна застосувати для вияву й аналізу інших феноменів ціннісно-смислового простору тексту книги спогадів Ірини Жиленко, а також увиразнити з огляду на специфіку осмислення феномена радості в поетичній творчості письменниці та в дискурсивно-текстовій діяльності різних мовних особистостей.

\section{ЛIТЕРАТУРА}

1. Арутюнова Н. Д. Типы модусов. Инверсия модуса и пропозиции. Арутюнова Н. Д. Язык и мир человека. Москва: «Языки русской культуры», 1999. С. 411-440. 2. Бацевич Ф. Смисл: сутність і сфери вияву в мові. Вісник Львів. ун-ту. Серія філол. Вип. 34. Ч. 1. 2004. С. 246-353. 3. Бацевич Ф. С. Дискурсивна прагматика: проблемне поле, дослідницька одиниця. Studia Linguistica: зб. наук. праць каф. заг. мовознав. КНУ ім. Т. Г. Шевченка. Київ: Вид.-полігр. центр «Київський університет», 2008. С. 4-10. 4. Бацевич Ф. С. Нариси з лінгвістичної прагматики. Львів: ПАІС, 2010. 336 с. 5. Бацевич Ф., Кочан І. Лінгвістика тексту. Львів: ЛНУ імені Івана Франка, 2016. 316 с. 6. Вайсбах Х., Дакс У. Эмоциональный интеллект. Москва: Лик Пресс, 1998. 160 с. 7. Гоулман Д. Емоційний інтелект. Харків: Vivat, 2018. 512 с. 8. Гуссерль Э. Идеи к чистой феноменологии и феноменологической философии. Москва: Лабиринт, 1994. 112c. 9. Гуссерль Э. Логические исследования. Т. ІІ (1). Гуссерль Э. Собрание сочинений. T. 3 (1). Москва: Дом интеллектуальной книги, 2001. 471 с. 10. Ермакова Е. В. Изучение синдрома эмоционального выгорания как нарушение ценностно-смысловой сферы личности (теоретический аспект). Культурно-историческая психология. 2010. №1. С. 27-39. 11. Жиленко Ірина. Ноmo feriens: Спогади. Київ: Смолоскип, 2011. 816 с. 12. Заоборна М. С. Краса як ціннісно-смисловий феномен в тексті книги спогадів Ірини Жиленко «Ноmo feriens». Лінгвістичні дослідження: Зб. наук. праць ХНПУ ім. Г. С. Сковороди. 2016. Вип. 43. С. 175-182. URL: https://dx.doi.org/10.5281/zenoclo.49226 13. Заоборна М. Людина в мереживі життя. Лінгвістичні студії: на пошану корифею: Зб. наук. праць івітань з нагоди 90-ліття від дня народження доктора філологічних наук, професора, заслуженого діяча науки і техніки України Сергія Івановича Дорошенка. Харків, 2014. С. 399-402. 14. Кононенко В. І. Смисл і текст. Київ, Івано-Франківськ: Вид-во Прикарпат. нац. ун-ту, 2012. 272 с. 15. Кримський С. Б. Запити філософських смислів. Київ: Вид. ПАРАПАН, 2003. 240 с. 16. Маринчак В. А. Интенциональное исследование ценностной семантики в художественном тексте. Харьков: Фолио, 2004. 287 с. 17. Мельчук И. А. Опыт теории лингвистических моделей «Смысл $\rightarrow$ Текст». Москва: Наука, 1974. 346 с. 18. Нестеренко В. Г. Вступ до філософії: онтологія людини. Київ: Абрис, 1995. 336 с. 19. Орел В. Е. Синдром психического выгорания личности. Москва: ИП РАН, 2005. 330 с. 20. Потебня А. А. Язык и народность. Потебня А. А. Мысль и язык. Киев: СИНТО, 1993. С. 158-185. 21. Сазонова Я. Ю. Варіації комунікативного смислу «страх» у текстах про зомбі в англомовній та українській лінгвокультурах. Записки з українського мовознавства. 2017. Том 2. № 24. С. 204-215. URL: https://doi.org/10.18524/2414-0627.2017.24.131424. 22. Словник української мови: в 11 т. Київ: Наукова думка, 1970-1980. Т. 8. 1977. 927 с. 23. Смирнова Н. М. Смысл и творчество. Москва: Издательство «Канон+» РООИ «Реабилитация», 2017. 304 с. 24. Шевченко Н. М. Языковая личность М. И. Цветаевой как объект лексикографии: автореф. дис. докт. филол. наук. Москва, 2014. 39 с. 


\section{REFERENCES}

1. Arutyunova, N. D. (1999). Tipy modusov. Inversiya modusa i propozitsii [Types of modi. Modus and proposition inversion]. Yazyk i mir chielovieka - The language and the world of man, (pp. 411-440). Moscow: «Yazyiki russkoi kultury» [in Russian]. 2. Batsevych, F. (2004). Smysl: sutnist i sfery vyiavu v movi [Sense: specificity and the spheres of expression in the language]. Visnyk Lviv. un-tu. Seriya filol. - Scientific papers of Lviv National University: Philology, 34 (part. 1), 246-353 [in Ukrainian]. 3. Batsevych, F. S. (2008). Dyskursyvna prahmatyka: problemne pole, doslidnytska odynytsia [Discourse pragmatics: problem field, research unit]. Studia Linguistica: zb. nauk. prats kaf. zah. movoznav. KNU im. T. H. Shevchenka - Studia Linguistica: Scientific collection of Kyiv National University named after Taras Shevchenko, (pp. 4-10). Kyiv: Vyd.-polihr. tsentr «Kyivskyi universytet» [in Ukrainian]. 4. Batsevych, F. S. (2010). Narysy z linhvistychnoi prahmatyky [The sketches of linguistic pragmatics]. Lviv: PAIS. [in Ukrainian]. 5. Batsevych, F., \& Kochan, I. (2016). Linhvistyka tekstu [Text linguistics]. Lviv: LNU imeni Ivana Franka [in Ukrainian]. 6. Vaysbah, H., \& Daks, U. (1998). Emotsionalnyi intelliekt [Emotional intelligence]. (A. Pavlov, Trans). Moscow: Lik Press [in Russian]. 7. Goulman, D. (2018). Emotsiinyi intelek [Emotional Intelligence]. (S.-L. Humetska, Trans). Kharkiv: Vivat [in Ukrainian]. 8. Gusserl, E. (1994). Idiei k chistoi fenomienologii i fenomienologichieskoi filosofii /The ideas for pure phenomenology and phenomenological philosophy]. (A. Mihaylov, Trans). Moscow: Labirint [in Russian]. 9. Gusserl, E. (2001) Logichieskie issliedovaniya [Logical investigations]. (V. Molchanov, Trans). Moscow: Dom intellektualnoy knigi [in Russian]. 10. Ermakova, E. V. (2010) Izuchienie sindroma emotsionalnogo vygoraniya kak narushenie tsennostno-smyslovoi sferyi lichnosti (tieorieticheskii aspiekt) [Research into the syndrome of emotional burnout as violation of value-sense sphere of a personality (theoretical aspect)]. Kulturno-istorichieskaya psihologiya - Cultural-historical psychology, 1, 27-39 [in Russian]. 11. Zhylenko, I. (2011). Homo feriens: Spohady [Homo feriens: Recollections]. Kyiv: Smoloskyp [in Ukrainian]. 12. Zaoborna, M. S. (2016). Krasa yak tsinnisno-smyslovyi fenomen v teksti knyhy spohadiv Iryny Zhylenko «Homo feriens» [Beauty as a value-sense phenomenon in the text of the book of recollections by Iryna Zhylenko «Homo feriens»]. Linhvistychni doslidzhennia: Zb. nauk. prats KhNPU im. H. S. Skovorody - Linguistic research: Collection of scientific papers of Kharkiv National Pedagogical University named after H. Skovoroda, 43, 175-182. Retrieved from https://dx.doi.org/10.5281/zenoclo.49226 [in Ukrainian]. 13. Zaoborna, M. (2014). Liudyna v merezhyvi zhyttia [Man in the lace of life]. L. A. Lysychenko, O. A. Oleksenko (Eds.), Linhvistychni studii: na poshanu koryfeyu - Linguistic studie: to commemorate the coryphaeus: Collection of scientific papers and congratulations on the occasion of 90-th anniversary of the doctor of sciences, professor, distinguished man in the sphere of science and technologies of Ukraine S. I. Doroshenko, (pp. 399-402). Kharkiv: Kharkivske istoryko-filolohichne tovarystvo [in Ukrainian]. 14. Kononenko, V. I. (2012). Smysl i tekst [Sense and text]. Kyiv, Ivano-Frankivsk: Vyd-vo Prykarpat. nats. un-tu [in Ukrainian]. 15. Krymskyi, S. B. (2003). Zapyty filosofskykh smysliv [Inventory of philosophical senses]. Kyiv: Vyd. PARAPAN [in Ukrainian]. 16. Marinchak, V. A. (2004). Intentsionalnoye issliedovanie tsennostnoy siemantiki v hudozhestviennom tiekstie [Intentional investigation of value semantics in the text of fiction]. Kharkiv: Folio [in Ukrainian]. 17. Melchuk, I. A. (1974). Opyt tieorii lingvistichieskikh modeliei «Smyisl $\rightarrow$ Tekst» [The experience of theory of linguistic models «Sense $\rightarrow$ Text»]. Moscow: Nauka [in Russian]. 18. Nesterenko, V. H. (1995). Vstup dofilosofii: ontolohiia liudyny [Introduction to philosophy: ontology of man]. Kyiv: Abrys [in Ukrainian]. 19. Orel, V. E. (2005). Sindrom psihichieskogo vygoraniya lichnosti /The syndrome of psychic burnout of a personality]. Moscow: IP RAN [in Russian]. 20. Potebnya, A. A. (1993). Yazyk i narodnost [Language and nationality]. Myisl i yazyik - Thought and language, (pp. 158-185). Kyiv: SINTO [in Ukrainian]. 21. Sazonova, Ya. Yu. (2017). Variatsii komunikatyvnoho smyslu «strakh» u tekstakh pro zombi v anhlomovnii ta ukrainskii linhvokulturakh [Variation of 
communicative sense "fear" in the texts abut zombie in English and Ukrainian lingocultures]. Zapysky z ukrainskoho movoznavstva - The writings of Ukrainian language studies, 24 (Vol. 2), 204-215. Retrieved from https://doi.org/10.18524/2414-0627.2017.24.131424 [in Ukrainian]. 22. Bilodid, I. K. (Ed.) (1977). Slovnyk ukrainskoi movy [The dictionary of Ukrainian]. (Vols. 1-11). Kyiv: Naukova dumka [in Ukrainian]. 23. Smirnova, N. M. (2017). Smysl $i$ tvorchiestvo [Sense and creativity]. Moscow: Izdatielstvo «Kanon» ROOI «Reabilitatsiya» [in Russian]. 24. Shevchenko, N. M. (2014). Yazykovaya lichnost M. I. Tsvietayevoi kak ob'yekt leksikografii [Marina I. Tsvietayeva's language personality as the object of lexicography]. Extended abstract of Doctor's thesis. Moscow: RUDN [in Russian].

Заоборна Марія Степанівна - кандидат філологічних наук, доцент, доцент кафедри загального мовознавства і слов'янських мов Тернопільського національного педагогічного університету імені Володимира Гнатюка; вул. Максима Кривоноса, 2, Тернопіль, 46027, Україна.

Tel.: + 380661058057

E-mail: maria_ternopil@ukr.net

http://orcid.org/0000-0001-6299-0060

Zaoborna Maria Stepanivna - PhD in Philology, Associate Professor, Department of General Linguistics and Slavic Languages, Volodymyr Hnatiuk Ternopil National Pedagogical University; M Kryvonosa Str., 2, Ternopil, 46027, Ukraine.

Надійшла до редакції 15 березня 2019 року 